\title{
THE EFFECTS OF BOTANICAL OILS ON THE RED PALM WEEVIL, RHYNCHOPHORUS FERRUGINEUS OLIVIER (COLEOPTERA: CURCULIONIDAE)
}

\author{
REYAD, N. F. ${ }^{1,2}-$ AL-GHAMDI, H. A. ${ }^{1}-$ ABDEL-RAHEEM, M. A. ${ }^{3 *}-$ AL-SHAERI, M. A. ${ }^{4}$ \\ ${ }^{1}$ Biology Department, College of Science, King Khalid University, Abha, Saudi Arabia \\ (e-mail: dr.huda.gh@gmail.com; phone: +966-567-000-464) \\ ${ }^{2}$ Plant Protection Research Institute A. R. C. Dokki, Giza, Egypt \\ (e-mail: drnagla@hotmail.com; phone: +966-559-206-370) \\ ${ }^{3}$ Pests \& Plant Protection Department, Agricultural and Biological Research Division, National \\ Research Centre, 33rd ElBohouth St., Dokki, Giza, Egypt \\ (e-mail: abdelraheem_nrc@hotmail.com,abdelraheem_nrc@yahoo.com; \\ phone: +201-155-527-583, +201-009-580-797; Orcid.org/0000-0001-9240-064X) \\ ${ }^{4}$ Department of Biological Sciences, Faculty of Science, King Abdulaziz University, Jeddah, \\ Saudi Arabia \\ (e-mail: malshaere@kau.edu.sa; phone: +966-567-000-464) \\ *Corresponding author \\ e-mail: abdelraheem_nrc@hotmail.com \\ (Received 29 $9^{\text {th }}$ Oct 2019; accepted $12^{\text {th }}$ Feb 2020)
}

\begin{abstract}
Date palm trees are liable to be attacked by many insect pests which cause serious damage to the different parts of tree. The most serious insect pest is the red palm weevil, Rhynchophorus ferrugineus (Oliver) (RPWs). To evaluate the impact of four botanical oils of Melissa officinalis, Borago officinalis, Laurus nobilis and Carapichea ipecacuanha on R. ferrugineus. 4 botanical oils were tested against newly emerged adults of $R$. ferrugineus for the purpose of investigating their insecticidal activity and effects on some biological aspects. Males of $R$. ferrugineus were more susceptible to the four botanical oils than females, followed by the immature larvae. The larvae showed different degrees of susceptibility to the four botanical oils. They showed the highest susceptibility to $C$. ipecacuanha and the lowest to B. officinalis oil at $\mathrm{LC}_{50}$ levels. Adult males and females were more susceptible to $C$. ipecacuanha and the least to $L$. nobilis oil at $\mathrm{LC}_{50}$ levels. The four tested oils disrupted some biological aspects of the insects. These oils remarkably reduced male and female longevity, female fecundity and hatchability of the laid eggs.
\end{abstract}

Keywords: effects, botanical oils, Rhynchophorus ferrugineus, control

\section{Introduction}

Date palm trees are liable to be attacked by a lot of insect pests. The most serious insect pest was the red palm weevil, Rhynchophorus ferrugineus (Oliver) (Saleh, 1992). Essential oils have high volatility and toxicity towards stored-grain pests and weevils (Regnault-Roger and Hamraoui, 1995; Regnault-Roger, 1997; Shaaya et al., 1997). Various chemical organic compounds have been isolated from plants; they include fixed oils, volatile oils and other plant constituents which expressed potential action against insect species. Extraction, isolation and identification of the fixed oils have been studied by Abdallah et al. (1986), Moustafa et al. (1986), Baraka and El-Hady (1993), Hussein and Shoukry (1997) and Shoukry-Karima (2003). El-Sayed et al. (1989) mentioned that maize oil and coconut oil used on Callosobruchus maculatus reduced their progeny. 
Abdel-Kawy and Gharib (1991) stated that oils of cotton seeds, sesame and peanut showed efficiency in treatment of yellow meal corn against the rice weevil, Sitophilus oryzae (L.). Jood et al. (1993) used neem oil (Azadirachta indica), powders of neem leaf and neem kernel, Citrus limon leaf, Allium sativum, Mentha spichata leaf in wheat grains at levels of $1 \%$ and $2 \%(\mathrm{w} / \mathrm{w})$ against larvae of Trogoderma granarium Everts and they found that neem products completely prevented damage by an introduced larval population. C. macculatus, adult emergence of was completely inhibited by castor oil, black seed oil and olive oil at concentration 1\% for 30 days (Swidan, 1996; Ismail et al., 2014, 2016; Salem et al., 2016). Also, the essential oils were tested against many insect species (Bouda et al., 2001; Isikber et al., 2006). The volatile oils of Boxus chinensis against 10 days-old larvae of the $R$. ferrugineus showed toxicological and pathological effects (Abdullah, 2009; Ahmed et al., 2015). Huseyin et al. (2006) noticed that ethanolic extracts of some aerial parts of lamiaceae species showed high larvicidal activity after 24 hours and M. officinalis (Linn.) oil was the highest toxic against larvae of Culex pipiens Linn. Karahroodi-Zahra et al. (2011) using of six essential oils from M. officinalis (L.), M. piperata (L.), P. sativum (Hoffman), L. angustifolia (Mill.), Z. clinopodioides (Lam.), and A. dracunculus (L.), on eggs and first instar larvae of $P$. interpunctella, they found that $M$. officinalis recorded moderate ovicidal activity. Ben Jemâa et al. (2011) studied the chemical composition and the repellent activity of Laurus nobilis essential oil against 7-10 days old-adults of the cigarette beetle, Lasioderma serricorne. The repellent action was highly dependent upon oil concentration and exposure time and L. nobilis essential oil may have potential as a control agent against this beetle. The essential oil of B. officinalis (L.) showed good larvicidal potential after 48 hours of exposure period against $A$. gambiae (Kweka et al., 2012). Essential oil of $L$. nobilis showed strong fumigant toxicity against $T$. granarium larvae (Tayoub et al., 2012). The ability of the aggregation pheromone to capture more females than males RPWs in the traps which makes trapping a potential tool for managing $R$. ferrugineus (Lee et al., 2001; Khalaf et al., 2009; El-Bokl et al., 2015). Powder of four plants, B. officinalis; M. piperta; Officinalis anisum; Eucalyptus glubulus was tested by Farman-Khansaa (2009) on the red flour beetle, Tribolium castaneum and found that $M$. piperta had most repellent efficiency plant, followed by $O$. anisum, E. glubulus, while the lowest was B. officinalis. The plant oils, (fixed and volatile) seriously disrupted some biological aspects of $R$. ferrugineus (Oliver) (Ahmed et al., 2015). Essential oils from various plants have shown promise as sources for insecticides. Earlier attempts to explore the toxicity of plant derivatives against $R$. ferrugineus have been made by essential oils. Two natural insecticides, Boxus chinensis oil and precocene II topically against larvae, prepupae and adult of red palm weevil, $R$. ferrugineus and the larvae of the palm beetle, pseudophilus testsceous. They found that larvae of $R$. ferrugineus were less tolerant to $B$. chinensis oil and more tolerant to precocene II than palm beetle larvae (Nassar and Abdullah, 2005). Nemazal and ethanolic neem extracts have a considerable significant remedial efficacy altogether with an effective, repellency against $R$. ferrugineus infestations (Merghem and Mohamed, 2017). An artificial diet incorporated with Picrotoxin was proven to inhibit the growth activities and to reprogram the detoxification defense mechanism of red palm weevils. Picrotoxin, a natural plant neurotoxin, is an important addition in the list of red palm weevil controlling products. Future research should focus on various aspects including formulation, safety, and application in order to optimize the e_cacy of Picrotoxin for managing red palm weevil infestations (Hussain et al., 2019). In this 
study, four botanical oils of Melissa officinalis, Borago officinalis, Laurus nobilis and Carapichea ipecacuanha were tested against newly emerged adult males and females of the red palm weevil, $R$. ferrugineus (Oliver) for investigating their insecticidal activity and effects on some biological aspects.

\section{Materials and Methods}

This study was carried out in Pests \& Plant Protection Department, National Research Centre, Giza, Egypt and Biology Department, College of Science, King Khalid University, Abha, Saudi Arabia.

\section{Mass rearing of $R$. ferrugineus}

Adults of Rhynchophorus ferrugineus were obtained from coccons collected from infested date palm trees, incubated in plastic boxes $(120 \times 60 \times 30 \mathrm{~cm})$. These coccons were kept in wet toweling till adult emergence. The newly emerged adults were sexually differentiated and fed on small pieces of red palm core.

\section{Used plants}

The plants under investigation were originally obtained from international markets, identified, divided into two groups fixed and volatile oils, these plants are listed in Table 1.

Table 1. Tested plants

\begin{tabular}{|c|c|c|c|c|}
\hline \multirow{2}{*}{ Group } & \multicolumn{2}{|c|}{ Plants } & \multirow{2}{*}{ Family name } & \multirow{2}{*}{ Used parts } \\
\hline & Common name & Scientific name & & \\
\hline $\begin{array}{c}\text { A } \\
\text { Fixed oils }\end{array}$ & $\begin{array}{l}\text { Lemon balm } \\
\text { Borage }\end{array}$ & $\begin{array}{l}\text { Melissa officinalis } \\
\text { Borago officinalis }\end{array}$ & $\begin{array}{c}\text { Lamiaceae } \\
\text { Boraginaceae }\end{array}$ & $\begin{array}{l}\text { Leaf } \\
\text { Leaf }\end{array}$ \\
\hline $\begin{array}{c}\text { B } \\
\text { Volatile oils }\end{array}$ & $\begin{array}{l}\text { Bay Laurel } \\
\text { Rio ipecac }\end{array}$ & $\begin{array}{c}\text { Laurus nobilis } \\
\text { Carapichea ipecacuanha }\end{array}$ & $\begin{array}{l}\text { Lauraceae } \\
\text { Rubiaceae }\end{array}$ & $\begin{array}{l}\text { Leaf \& fruit } \\
\text { Root \&leaf }\end{array}$ \\
\hline
\end{tabular}

\section{Oils extraction}

Extraction of fixed oils was performed from crushed and previously steam distilled plant parts of group A, where the dry powdered plants were macerated in petroleum ether (40/60) according to Harbourne (1984) and El-Sayed et al. (1989). The petroleumether extracts were filtered through anhydrous sodium sulphate. The solvent was removed by using rotary evaporator. The volatile oils were extracted from plants in group $\mathrm{B}$, by using steam distillation technique according to the method of Anderson et al. (1980). Then oils were saturated with sodium chloride and extracted again with diethyl ether. The extracts were dried over anhydrous sodium sulphate and evaporated under reduced pressure by using rotary evaporator apparatus.

\section{Methods of bioassay}

The concentrations of the two groups of oils were prepared and added $0.1 \%$ tween to the fixed oil as an emulsifier. Pieces of date palm hearts were rinsed in each concentration for 20 seconds, and left to dry at room temperature. Treated pieces were 
put separately in all replicates of pairs of newly emerged adults or 8 days-old larvae of the second generation. 100 (larvae, and adults) were used for each treatment, divided into 4 groups, each of 25 (larvae, and adults) were placed in Petri dishes, one individual/dish. For each concentration individuals of larvae were counted after 7 days and after 10 days for adults after treatments under laboratory conditions $\left(30^{\circ} \mathrm{C}, 75 \pm 5 \%\right.$ R.H., and 12D : $12 \mathrm{~L} \mathrm{hrs.)} \mathrm{to} \mathrm{determine} \mathrm{the} \mathrm{\%} \mathrm{mortality.}$

\section{Analysis of results}

Toxicity lines were established and $\mathrm{LC}_{50}$ values were determined. The Toxicity lines were analyzed according to the method described by Finney (1952). The slope function and the relative potency of the tested oils were determined according to Sun (1950).

\section{Results}

Table 2 showed that the $C$. ipecacuanha was the highest toxic to the larvae $\left(\mathrm{LC}_{50}=1260.09 \mathrm{ppm}\right)$, followed by $L$. nobilis oil $\left(\mathrm{LC}_{50}=2412.30\right)$ and then B. officinals $\left(\mathrm{LC}_{50}=2500.71 \mathrm{ppm}\right)$. The relative potencies based on $C$. ipecacuanha were 1.20, 1.87 and 1.90 for M. officinalis, B. officinalis and L. nobilis, respectively. The relatively low values of slope functions revealed the homogenous response of the tested stages to the different concentrations of the tested oils.

Table 2. Toxicity and the relative potency of the fixed oils and volatile oils on $R$. ferrugineus

\begin{tabular}{|c|c|c|c|c|}
\hline \multicolumn{5}{|c|}{8 days-old larvae: } \\
\hline Botanical oil & Tested plant & $\begin{array}{c}\mathbf{L C}_{50}(\mathrm{ppm}) \\
\text { (Confidence limits) }\end{array}$ & $\begin{array}{c}\text { Slope } \\
\text { function }\end{array}$ & $\begin{array}{l}\text { Relative } \\
\text { potency }\end{array}$ \\
\hline \multirow{2}{*}{$\begin{array}{l}\text { Fixed } \\
\text { oils }\end{array}$} & & $\begin{array}{c}1600.635 \\
(1260.820-2010.140)\end{array}$ & 2.300 & 1.200 \\
\hline & Borago officinalis & $\begin{array}{c}2500.712 \\
(2368.900-2652.556)\end{array}$ & 4.333 & 1.871 \\
\hline \multirow{2}{*}{$\begin{array}{l}\text { Volatile } \\
\text { oils }\end{array}$} & Laurus nobilis & $\begin{array}{c}2412.300 \\
(2288.700-2522.806)\end{array}$ & 5.233 & 1.900 \\
\hline & Carapichea ipecacuanha & $\begin{array}{c}1260.093 \\
(1030.866-1510.820) \\
\end{array}$ & 2.533 & 1 \\
\hline \multicolumn{5}{|c|}{ Adult females: } \\
\hline \multirow{2}{*}{$\begin{array}{l}\text { Fixed } \\
\text { oils }\end{array}$} & Melissa officinalis & $\begin{array}{c}1280.556 \\
(1140.284-1460.300)\end{array}$ & 2.000 & 1.200 \\
\hline & Borago officinalis & $\begin{array}{c}1350.210 \\
(1230.500-1500.239) \\
\end{array}$ & 2.500 & 1.270 \\
\hline \multirow{2}{*}{$\begin{array}{l}\text { Volatile } \\
\text { oils }\end{array}$} & Laurus nobilis & $\begin{array}{c}1880.763 \\
(1778.800-2000.500)\end{array}$ & 4.400 & 1.755 \\
\hline & Carapichea ipecacuanha & $\begin{array}{c}1060.500 \\
(960.800-1170.130) \\
\end{array}$ & 2.457 & 1 \\
\hline \multicolumn{5}{|c|}{ Adult males: } \\
\hline \multirow{2}{*}{$\begin{array}{l}\text { Fixed } \\
\text { oils }\end{array}$} & Melissa officinalis & $\begin{array}{c}1130.75 \\
(1023.744-1252.700)\end{array}$ & 2.320 & 1.290 \\
\hline & Borago officinalis & $\begin{array}{c}1248.155 \\
(970.053-1515.300) \\
\end{array}$ & 3.120 & 1.400 \\
\hline \multirow{2}{*}{$\begin{array}{l}\text { Volatile } \\
\text { oils }\end{array}$} & Laurus nobilis & $\begin{array}{c}1750.645 \\
(1440.210-2020.120)\end{array}$ & 4.400 & 2.000 \\
\hline & Carapichea ipecacuanha & $\begin{array}{c}870.721 \\
(780.840-970.900) \\
\end{array}$ & 2.111 & 1 \\
\hline
\end{tabular}


Table 3 showed a highly significant decrease in both male and female longevity of $R$. ferrugineus when treated with the plant oils of $M$. officinalis and B. officinalis as fixed oils; L. nobilis and $C$. ipecacuanha as volatile oils. Also, the treatment with the tested plant oils of M. officinalis, B. officinalis, C. ipecacuanha and L. nobilis showed a high significant reduction on the fecundity. Hatching percentage of eggs laid by adult females treated with the all tested oils decreased significantly. The hatching percentages were $55.3 \pm 0.22 \%$ and $64.2 \pm 0.24 \%$ in case of treatment with $C$. ipecacuanha, and L. nobilis volatile oils, respectively. While the hatching percentages in case of treatment with the two fixed oils reached $58.8 \pm 0.3 \%$ in $M$. officinalis and $59.09 \pm 0.21 \%$ in B. officinalis oil.

Table 3. Effect of $\left(L C_{50}\right)$ of plant oils on biological aspects of newly emerged adults of R. ferrugineus

\begin{tabular}{|c|c|c|c|c|c|c|c|c|c|}
\hline \multirow{2}{*}{\multicolumn{2}{|c|}{ Treatment }} & \multicolumn{2}{|c|}{$\begin{array}{l}\mathbf{L C}_{50} \\
(\mathbf{p p m})\end{array}$} & \multicolumn{2}{|c|}{$\begin{array}{l}\text { Adult longevity (days) } \\
\quad \text { Mean } \pm \text { S.E. }\end{array}$} & \multirow{2}{*}{$\begin{array}{c}\text { Fecundity } \\
(\text { eggs/ } / \text { ) } \\
\text { Mean } \pm \\
\text { S.E. }\end{array}$} & \multirow{2}{*}{$\begin{array}{c}(\text { Eggs } / q / \\
\text { day }) \\
\text { Mean } \pm \\
\text { S.E. }\end{array}$} & \multirow{2}{*}{$\begin{array}{c}\text { Fertility } \\
(\text { eggs/ }+ \text { ) } \\
\text { Mean } \pm \\
\text { S.E. }\end{array}$} & \multirow{2}{*}{$\begin{array}{c}\text { Hatching } \\
\text { percentage } \\
(\%) \\
\text { Mean } \pm \\
\text { S.E. }\end{array}$} \\
\hline & & $\sigma^{\pi}$ & 우 & $\hat{0}$ & q & & & & \\
\hline \multicolumn{2}{|r|}{ Control } & \multicolumn{2}{|c|}{--------- } & $\begin{array}{c}140 \\
\pm 3.10\end{array}$ & $\begin{array}{l}130.23 \\
\pm 3.08\end{array}$ & $\begin{array}{c}148 \\
\pm 2.20\end{array}$ & $\begin{array}{c}2.40 \\
\pm 0.02\end{array}$ & $\begin{array}{l}135.13 \\
\pm 0.42\end{array}$ & $\begin{array}{l}89.70 \\
\pm 1.3\end{array}$ \\
\hline \multirow{2}{*}{ Fixed oils } & $\begin{array}{c}\text { Lemon balm } \\
\text { (Melissa } \\
\text { officinalis) } \\
\end{array}$ & 1138 & 1288 & $\begin{array}{c}75.2 \\
\pm 4.33 * *\end{array}$ & $\begin{array}{c}82.45 \\
\pm 2.2 * *\end{array}$ & $\begin{array}{c}95.20 \\
\pm 2.80^{* *}\end{array}$ & $\begin{array}{c}1.13 \\
\pm 0.52 * *\end{array}$ & $\begin{array}{c}56.0 \\
\pm 1.83 * *\end{array}$ & $\begin{array}{c}58.8 \\
\pm 0.3^{* *}\end{array}$ \\
\hline & $\begin{array}{c}\text { Borage (Borago } \\
\text { officinalis) }\end{array}$ & 1357 & 1368 & $\begin{array}{c}92.0 \\
\pm 4.52 * *\end{array}$ & $\begin{array}{c}103.65 \\
\pm 8.10^{* *}\end{array}$ & $\begin{array}{c}120.0 \\
\pm 1.79 * *\end{array}$ & $\begin{array}{c}1.10 \\
\pm 0.15^{* *}\end{array}$ & $\begin{array}{c}72.30 \\
\pm 1.66^{* *}\end{array}$ & $\begin{array}{c}59.02 \\
\pm 0.21 * *\end{array}$ \\
\hline \multirow{2}{*}{$\begin{array}{l}\text { Volatile } \\
\text { oils }\end{array}$} & $\begin{array}{c}\text { Bay leaf (Laurus } \\
\text { nobilis) }\end{array}$ & 1753 & 1880 & $\begin{array}{l}102.57 \\
\pm 3.2 * *\end{array}$ & $\begin{array}{l}112.30 \\
\pm 3.2 * *\end{array}$ & $\begin{array}{r}134.65 \\
\pm 3.33^{* *}\end{array}$ & $\begin{array}{c}1.1 \pm \\
0.02 * *\end{array}$ & $\begin{array}{l}85.65 \\
\pm 2.1^{* *}\end{array}$ & $\begin{array}{c}64.2 \\
\pm 0.24 * *\end{array}$ \\
\hline & $\begin{array}{c}\text { Rio ipecac } \\
\text { (Carapichea } \\
\text { ipecacuanha) }\end{array}$ & 875 & 1050 & $\begin{array}{c}61.61 \\
\pm 3.2 * *\end{array}$ & $\begin{array}{c}68.0 \\
\pm 6.16^{* *}\end{array}$ & $\begin{array}{c}75.32 \\
\pm 8.30^{* *}\end{array}$ & $\begin{array}{c}1.12 \\
\pm 0.11^{* *}\end{array}$ & $\begin{array}{c}42.47 \\
\pm 4.20^{* *}\end{array}$ & $\begin{array}{c}55.3 \\
\pm 0.22 * *\end{array}$ \\
\hline
\end{tabular}

Without * Non significant $(\mathrm{P}>0.05)$ * Significant $(\mathrm{P}<0.05)$. ** highly significant $(\mathrm{P}<0.001)$

Table 4 showed that, there was significant increase in larval duration in case of treatment with the volatile oils while statistical analysis of the decrease in the larval duration in case of treatment with the two fixed oils of M. officinalis and B. officinalis was not significant. Significant increase in prepupal and pupal durations occurred by the treatment with $C$. ipecacuanha as it reached $7.0 \pm 0.34$ and $11.3 \pm 1.2$ days, respectively. While treatment with fixed oils of $M$. officinalis and $B$. officinalis decreased non significantly in the prepupal and pupal durations. High significant reduction in the pupation percentage of treated larvae reached $40.2 \pm 0.2 \%$ by $C$. ipecacuanha, $54.2 \pm 2.0 \%$ by $M$. officinalis, $60.2 \pm 1.2 \%$ by B. officinalis, and $60.2 \pm 2.2 \%$ by L. nobilis, while that, of control was $90.0 \pm 0.0 \%$. The 8 days treatment of old-larvae with $\left(\mathrm{LC}_{50}\right)$ of plant oils (fixed oils and volatile oils) resulted in high significant reduction of adult emergence (\%). Both male and female longevity also decreased significantly when treated by the two fixed oils and volatile oils and showed high significant decrease in their duration when treated with $C$. ipecacuanha. The tested plant oils had variable effects on fecundity of females emerged from treated larvae. The mean number of eggs deposited by a female decreased high significantly in case of treatment with C. ipecacuanha oil and was non-significant in case of treatment with M. officinalis, 
B. officinalis and L. nobilis. Also, Table 4 showed non-significant decrease in hatching (\%) of eggs laid by females emerged from treated larvae except that, of C. ipecacuanha, which showed a significant decrease. It was clear that, the plant oils (both the fixed and volatile) seriously disrupted some biological aspects of $R$. ferrugineus (Oliver).

Table 4. Effect of $\left(L C_{50} S\right)$ of plant oils on different biological aspects of 8 days old larvae of R. ferrugineus

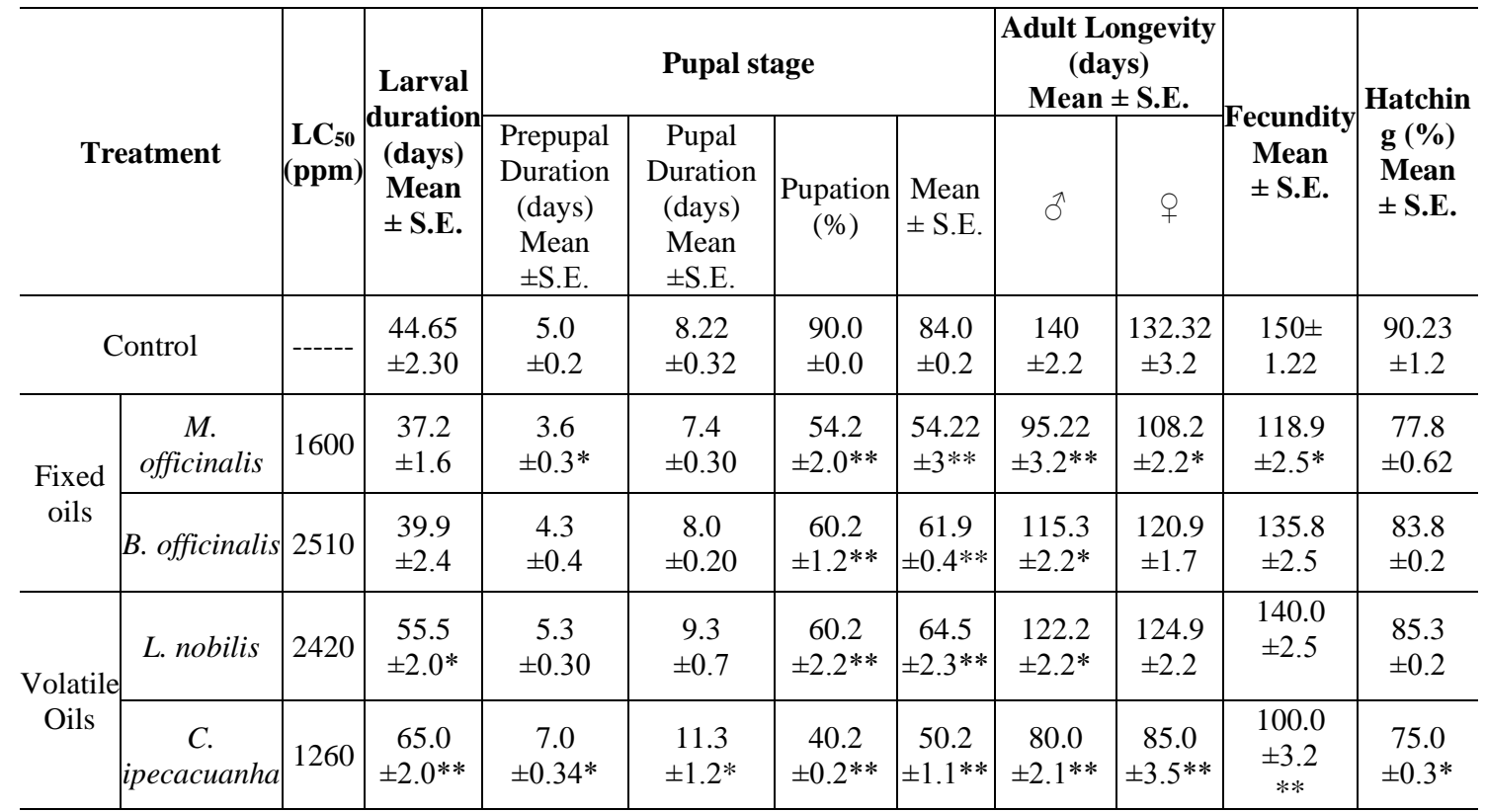

Without * Non significant $(\mathrm{P}>0.05)$ * Significant $(\mathrm{P}<0.05) . * *$ highly significant $(\mathrm{P}<0.001)$

\section{Discussion}

Essential oils from many plants have become promising sources of insecticides. Several attempts to explore the toxicity of plant derivatives against $R$. ferrugineus have been made by by the use of essential oils. Nassar and Abdullah (2005) tested two natural insecticides, Boxus chinensisoil and precocene II topically against larvae, prepupae and adult of red palm weevil, $R$. ferrugineus and the larvae of the palm beetle, pseudophilus testsceous. They found that larvae of $R$. ferrugineus were less tolerant to B. chinensis oil and more tolerant to precocene II than palm beetle larvae. Huseyin et al. (2006) studied the larvicidal activity of ethanolic extracts of some arial parts of Lamiaceae species against Culex pipiens (Linn.). They found that all plant extracts had strong larvicidal activity after 24 hours exposure tests. Melissa officinalis (Linn.) oil showed the highest toxic activity. Abdullah (2009) tested the volatile oil of Boxus chinensis against 10-day old larvae of the red palm weevil, $R$. ferrugineus. He found that it had toxicological and pathological effects on $R$. ferrugineus larvae. The results of the current study, concerning the toxicity of the four botanical oils to the 8-day old larvae and adults of $R$. ferrugineus, showed that the (C. ipecacuanha) oil was superior to the other three oils of lemon palm (M. officinalis), Bay leaf (L. nobilis) and the borage (B. officinalis) oils, while Borage was the least toxic oil. The variation in the toxicological effects of the tested oils might be due to differences in their chemical composition as well as the variation in sensitivity and response to the various cells and 
tissues. This might also depend on the amount of poison that reaches the site of action. Mostafa et al. (1995) mentioned that the volatile oils of some plants increased the activity of Malic Dehydrogenase Enzyme (MDE) and decreased the activity of (Malic Enzyme) (ME) in Pectinophora gossypiella and Erias insulana larvae. From the above mentioned data we concluded that the two fixed and the two volatile oils caused a similar significant decrease in both male and female longevities. This result is in line with findings of Andronikashvili and Reichmuth's study (2003) who concluded that the volatile oil of $L$. nobilis had high repellency effect towards adult of red flour beetle, Tribolium castaneum explaining its moderate insecticidal activity and reducing periods of male and female longevity. Similar results were obtained by Isikber et al. (2006). Farman-Khansaa (2009) investigated the repellent effect of powder of four plants; B. officinalis, M. piperta, O. anisum and Eucaluptus glubulus against the red flour beetles Tribolium castanium, reflecting the first essential reason of weevil longevities decrease, which is due to their high repellency. The same high repellency was recorded by Ben Jemâa et al. (2011) against adults of the cigarette beetle Lasioderma serricorne, and also led to decrease in adult longevity. Also Mohamad et al. (2011) studied the causes of attraction and repellency effect of some plants extracts from leaves and roots of Borago and Tages plant against the Southern cowpea weevil, C. maculates (Fab.). The results showed significant differences in attraction and repellency effect according to the kind of extracted plant and concentration. When repellency occurs, it refers to the major reason of dramatical weevil longevity decrease. The same result was achieved by the volatile oil and this is similar to the results obtained by Karahroodi-Zahra et al. (2009) who came to the concusion that the volatile oils of $M$. officinalis had a moderate repellency against adults of $P$. interpunctella reflecting the first essential reason of weevil longevities decrease. Furthermore, the present study revealed that both fixed and volatile oils caused a significant decrease in both male and female longevities. This result was confirmed by Andronikashvili and Reichmuth (2003) who illustrated that the volatile oil of $L$. nobilis had high repellency effect towards adult of red flour beetle, T. Castaneum. Similar results were obtained by Isikber et al. (2006). The present study revealed that, fixed oils remarkably decreased the average number of eggs deposited by treated females. This was confirmed by the findings of Schoonhoven (1978) and Shankaranarayana et al. (1979). Singh et al. (1978) mentioned that, groundnut oil prevented the emergence of progeny rather than affecting the oviposition of C. maculates. Abdel-Kawy and Gharib (1991) indicated that cotton seed oil, sesame, peanut and paraffin oils reduced the number of progeny in Sitophilus oryzae. Taheya and Al-Moagel (1993) indicated that tumeric extract reduced the khapra beetle F1 progeny, and interfered with its development. Regnault-Roger and Hamraoui (1995) showed that the volatile oils of $L$. nobilis could protect kidney beans by direct or delayed insecticidal effect through increased adult mortality and inhibition of beetle reproduction of Acanthoscelides obtectus (Say). Also, the authors of this study concluded that the treatments by fixed and volatile oils had a significant effect on the reproductive potential of $R$. ferrugineus (Oliver). The average number of eggs laid per female as well as hatching (\%) was reduced significantly. Similar results related to the fecundity of other treated insects with volatile oils were obtained by several authors (Frik and Nazirov, 1981; Dongre and Rahalkar, 1982). Nassar (1995) stated that complete sterility of Muscina stabulans adult was achieved by larval treatment with some plant extracts and Hussein (1995) reported that treatment of the second larval instar of Parasarcophaga aegyptiaca with some volatile plant oils induced a remarkable 
reduction in reproductive potential of developing adults. Shoukry-Karima (2003) stated that the tested plant volatile oils of Pipe rcubebae and Sativa officinalis had a high significant decrease effect on pupation percentage, adult emergence percentage, fecundity, fertility and hatchability of females emerged from treated larvae of P. interpunctella. In contrast, Singh et al. (1989) found that volatile oils extracted from Callicarpa macrophylla and Zanthoxylum alatum plant increased the fecundity of S. oryzae and Sitophilus granarius. Karahroodi-Zahra et al. (2011) referred to the great toxicity of the volatile essential oils of $M$. officinalis against the first instar larvae and eggs of $P$. interpunctella leading to significant decrease in the number of hatched eggs. Karahroodi-Zahra et al. (2008) investigated fumigant toxicity of the essential oil from $M$. officinalis L. against first instar larvae and eggs, of $P$. interpunctella (Hübner) showing moderate ovicidal and egg deterrence effect against this pest. Nassar and Abdullah $(2001,2005)$ recorded some pupal morphogenetic abnormalities of the red palm weevil resulting in incomplete adult eclusion due to the treatment with azadirachtin and Boxus chinensis. The same result was also reported by Bream et al. (2001). As most of the puparia failed to reach adults (aborted puparia).

\section{Conclusion}

The four tested oils disrupted some biological aspects of the tested insects. These oils remarkably reduced male and female longevity, female fecundity and hatchability of the laid eggs. In the future the authors will use it as Nano Particles against the insects to get more effects on the insects.

Acknowledgements. The authors extend their appreciation to the Deanship of Scientific Research at King Khalid University, Abha, KSA for funding this study through Research Groups Program under grant number (R.G.P.1/78/40).

Conflict of Interests. No conflict of interests associated with this work.

\section{REFERENCES}

[1] Abdallah, M. D., Kandil, M. A., Farag, A. A. (1986): Isolation and identification of biologically active compounds from extracts of Minteena, Barnoof and Ullaiq. - Bull. Entomol. Soc. Egypt. Econ. Ser. 15: 191-197.

[2] Abdel-Kawy, F. K., Gharib, O. H. (1991): Treatment with different oils for the control of rice weevil, Sitophilus oryzae (L.), in yellow meal corn. - Bull. Entomol. Soc. Egypt. Econ. Ser. 19: 115-119.

[3] Abdullah, M. A. R. (2009): Toxicological and histopathological studies of Boxus chinensis oil and precocene II on larvae of the red palm weevil, Rhynchophorus ferrugineus (Oliver) (Coleoptera: Curculionidae). - Egypt. Acad. J. biol. Sci. 2(2): 45-54.

[4] Ahmed, F. A., Hussein, K. T., Gad, M. I. (2015): Biological activity of four plant oils, against the red palm weevil, Rhynchophorus ferrugineus (Oliver), (Coleoptera: Curculionidae). - Journal of Bioscience and Applied Research 1(5): 213-222.

[5] Anderson, B. A., Holman, R. T., Lundgren, L., Stenhagen, G. (1980): Capillary gaschromatogrpahy of leaf volatiles. A possible aid to breeders for pest and disease resistance. - J. Agric. Food Chem. 28: 985-989.

[6] Andronikashvili, M., Reichmuth, C. (2003): Repellency and toxicity of essential oils from Ocimum gratissimum (Lamiaceae) and Laurus nobilis (Lauraceae) from Georgia against 
the rust-red flour beetle (Tribolium castaneum Herbst) (Coleoptera: Tenebrionidae). Advances in Stored Product Protect: 749-762.

[7] Baraka, D. M., El-Hady, A. F. (1993): Comparative study of seed lipid constitutents of four species of family Faraceae. - Egypt. J. App. Sci. 8(3): 44-49.

[8] Ben Jemâa, J. M., Tersim, N., Khouja, M. L. (2011): Composition and repellent efficacy of essential oil from Laurus nobilis against adults of the Cigarette Beetle Lasioderma serricorne (Coleoptera: Anobiidae). - Tunisian J. Plant Protect 6(1): 29-42.

[9] Bouda, H., Tapondjou, L. A., Fontem, D. A., Gumedzoe, M. Y. D. (2001): Effect of essential oils from leaves of Ageratum conyzoides, Lantana camara and Chromolaena odorataon on the mortality of Sitophilus zeamais (Coleoptera, Curculionidae). - J. Stored Prod. Res. 32(2): 153-164.

[10] Bream, A. S., Ghoneim, K. S., Tanani, M. A., Nassar, M. M. (2001): Respiratory metabolic risponsiveness, during the pupal stage of the red palm weevil to certain plant exeracts. - Med. Fac. Landbouww. Univ. Gent 66(2): 491-502.

[11] Dongre, T. K., Rahalkar, G. W. (1982): Effect of Blumea eriantha (Compositae) oil on reproduction in Earias vittella (F.). - Experientia 38(1): 98-99.

[12] El-Bokl, M. M., Sallam, A. M., Abdallah, G. A., Gabr, B. M., (2015): Efficay of aggregation pheromone in trapping red palm weevil (Rhynchophorus ferrugenious Olivier) infested Date palms in Damietta, Egypt. - Egypt. Acad. J. Biolog. Sci. 7(1): 5159.

[13] El-Sayed, F. M. A., Etman, A. A., Abdel-Razik, M. (1989): Effectiveness of natural oils in protecting some stored products from two stored product pests. - Bull. Fac. Agric., Cairo Univ. 40(2): 409-418.

[14] Farman-Khansaa, S. (2009): The repellency effect of powder of many plants on red flour beetles Tribolium castanium. - Dialy Agric. Sci. J. 1(2): 18-24.

[15] Finney, D. J. (1952): Probit analysis: a statistical treatment of the sigmoid response curves. $-2^{\text {nd }}$ ed. Cambridge Univ. Press.

[16] Frik, L. P., Nazirov, Z. N. (1981): Components of Euphorbia jaxaritica CF. - Chem. Abst. 95(9): 3467.

[17] Gujar, G. T., Mehrotra, K. N. (1983): Juvenilizing effect of azadirachtin on noctuid moth, Sopodoptera litura Fabr. - Indian J. Exp. Biol. 21: 292-293.

[18] Harborne, J. B. (1984): Phytochemical Methods. - Second Edition, pp 150-160. Chapman \& Hall. London, New York.

[19] Huseyin, C., Ilker, C., Atila, Y., Mustafa, G. (2006): Larvicidal activity of some labiatae (Lamiaceae) plant extracts from Turkey. - Phytother Res. 20(12): 1088-1090.

[20] Hussain, A., Rizwan-ul-haq, M., Mohammed, A., Al-Ayedh, H. (2019): Lethality of Sesquiterpenes Reprogramming Red Palm Weevil Detoxification Mechanism for Natural Novel Biopesticide Development. - Molecules 24: 1648.

[21] Hussein, K. T. (1995): Effect of some plant extracts in the control of a non-biting Muscoid fly. - Ph.D. Thesis, Fac. Sci. Zag. Univ., Egypt.

[22] Hussein, K. T., Shoukry, I. F. (1997): Toxicological and histopathological studies of certain plant fixed oils on Culex pipiens larvae. - Ain Shams Sci. Bull. 35: 287-305.

[23] Isikber, A. A., Alma, M. H., Kanat, M., Karci, A. (2006): Fumigant toxicity of essential oils from Laurus nobilis and Rosmarinus officinalis against all life stages of Tribolium confusum. - Phytoparasitica 34(2): 167-177.

[24] Ismail, I. A., Farg, N. A., Abdel-Rahman, R. S., Abdel-Raheem, M. A., Radwan, H. M. (2014): Insecticidal activity of some plant extracts rich in coumarin against cowpea beetle, Callosobruchus maculatus (Fab.) (Coleoptera: Bruchidae). - Egyptian Journal of Biological Pest Control 24(2): 465-469.

[25] Ismail, I. A., Abdel-Rahman, R. S., Abdel-Raheem, M. A. (2016): Utilization of certain plant extracts and entomopathogenic fungi for controlling the black fig fly, Lonchaea aristella on fig trees. - International Journal of Chem Tech Research 9(4): 35-42. 
[26] Jood, S., Kapoor, A. C., Singh, R. (1993): Evaluation of some plant parts against Trogoderma granarium Everts in stored wheat and their effect on nutritional composition and organoleptic characteristics of treated grains. - Int. J. Pest. Manag. 39(1): 93-98.

[27] Karahroodi-Zahra, R., Moharramipour, S., Farazmand, H., Karimzadeh-Esfahani, J. (2008): Effect of eighteen plant essential oils on nutritional indices of larvae Plodia interpunctella Hubner (Lep.: Pyralidae). - Entomol. J. Res. Islamic Azad Univ., Arak Branch 1(3): 209-219.

[28] Karahroodi-Zahra, R., Moharramipour, S., Rahbarpour, A. (2009): Original articles investigated repellency effect of some essential oils of 17 native medicinal plants on adults Plodia interpunctella. - American-Euras J. of Sustainable Agric. 3(2): 181-184.

[29] Karahroodi-Zahra, R., Moharramipour, S., Farazmand, H., Karimzadeh-Esfahani, J. (2011): Insecticidal effect of six native medicinal plants essential oil on Indian meal moth, Plodia interpunctella Hübner (Lep.: Pyralidae). - Munis Entomol and Zool. 6(1): 339-345.

[30] Khalaf, A. F. A., Hussein, K. T., Shoukry, K. K. (2009): Biocidal activity of two botanical volatile oils against the larvae of Synthesiomyia nudiseta (Wulp) (Diptera: Muscidae). - Egypt. Acad. J. Biol. Sci. 2(1): 89-101.

[31] Kweka, E. J., Senthilkumar, A., Venkatesalu, V. (2012): Toxicity of essential oil from Indian borage on the larvae of the African malaria vector mosquito, Anopheles gambiae. - Parasites \& Vectors J. 277(5): 1-5.

[32] Lee, B. H., Choi, W. S., Lee, S. E., Park, B. S. (2001): Fumigant toxicity of essential oils and their constituent compounds towards the rice weevil, Sitophilus oryzae (L.). - Corp protection 20: 317-320.

[33] Merghem, A., Mohamed, A. (2017): Impact of Neem Extracts, Azadirachta indica A. Juss Induced against Red Palm Weevil, Rhynchophorus ferrugineus (Olivier) Attacking Date Palm Orchards in Egypt. - Egypt. Acad. J. Biolog. Sci. 9(2): 109-117.

[34] Mohamad, A. H., Obadi, A. K., Ramdan, F. M. (2011): Attraction, repellency and toxic effect of some plant extracts on the Southern cowpea weevil Callosobruchus maculates (Fab.) (Coleoptera: Bruchidae). - Tekrit Agric. Sci. J. 11(2): 204-209.

[35] Mostafa, Z. K., El-Sherif, L. S., Hewady, M. A. A. (1995): Effect of certain volatile plant oils on the activity of malate dehydrogenase and malic enzyme in Pectinophora gossypiella (Saun.) and Earias insulana (Boisd) larvae (Lepidoptera: Noctuidae). - J. Egypt. Ger. Soc. Zool. 17: 13-23.

[36] Moustafa, S. M., Kadry, H. A., El-Olemy, M. M., Bisher, M. M. (1986): Lipids, pigments and saponines of Sansevieria cylindrica, Bjor. - Bull. Pharm. Sci., Assuit. Univ. 9(1): 1.

[37] Nassar, M. I. (1995): The potential of some juvenoids precocenes and botanical extracts for the control of Muscina stabulans (Fallin). - Ph.D. Thesis, Fac. Sci. Cairo University, Egypt.

[38] Nassar, M. M., Abdullah, A. A. (2001): Evaluation of Azadirachtin for control of the red palm weevil Rhynchophorus ferrugineus (Oliver). - J. Egypt. Ger. Soc. Zool. Entomol. 36: 163-173.

[39] Nassar, M. I., Abdullah, A. M. (2005): Assessement of Boxus chinensis oil and Precocene II for the control of the red palm weevil, Rhynchophorus ferrugineus (Oliver) (Coleoptera-Curculionidae) and the palm beetle Pseudophilus testsceous (Gahan) (Coleoptera-Cerambycidae). - J. Entomol. 2(1): 1-8.

[40] Regnault-Roger, C., Hamraoui, A. (1995): Comparison of the insecticidal effects of water extracted and intact aromatic plants on Acanthoscelides obtectus, a bruchid beetle pest ofkidney beans. - Chemoecology 5: 1-5.

[41] Regnault-Roger, C. (1997): The potential of botanical essential oils for insect pest control. - Integrated Pest Management Reviews 2: 25-34.

[42] Saleh, M. R. A. (1992): Red palm weevil, Rhynchophorus ferruginous (Oliver) in the first record for Egypt and indeed the African continent list No: 10634 Africa collection. International Institute of Entomol. 56 Queen5 gate. London, Sw., 75 JR.UK. 
[43] Salem, S. A., Abd El-Salam, A. M. E., Abdel-Raheem, M. A., Farage, N. A., El-Hawary, F. M. (2016): Field studies to assess the efficiency of bio-extracts against the scourge of onion crops, Thrips tabaci Lindeman in Egypt. - Der Pharma Chemica 8(20): 74-77.

[44] Schoonhoven, A. V. (1978): Use of vegetable oils to protect stored beans from Bruchid attack. - J. Econ. Entomol. 71(2): 254-256.

[45] Shaaya, E., Kostjukovski, M., Eilberg, J., Sukprakarn, C. (1997): Plant oils as fumigants and contact insecticides for the control of stored-product insects. - J. Stored-Prod. Res. 33: 7-15.

[46] Shankaranarayana, K. H., Shivaramakrishnan, U. R., Ayyar, K. S., Sarma, P. A. (1979): Isolation of a compound from the barch of sandal Santhalum album (L.) and its activity against some lepidopterous and coleopterous insects. - J. Entomol. Res. 3(1): 116-118.

[47] Shoukry-Karima, K. (2003): Toxicological effects of botanical extracts against some stored product insects. - M.Sc. Thesis, Fac. Sci. Zagazig Univ.

[48] Singh, S. R., Luse, R. A., Leuschner, K., Nangju, D. (1978): Groundnut oil treatment for the control of Callosobruchus maculatus (F.). - J. Stored Prod. Res. 14(2-3): 77-80.

[49] Singh, D., Siddiqui, M. S., Sharma, S. (1989): Reproductive retardant and fumigant properties in essential oils against rice weevil (Coleoptera: Curculionidae) in stored wheat. - J. Econ. Entomol. 82(3): 227-233.

[50] Sun, Y. P. (1950): Toxicity index: an improved method of comparing the relative toxicity of insecticides. - J. Econ. Entomol. 43: 45-53.

[51] Swidan, M. H. (1996): Effectiveness of some vegetable oils in protecting blackeyed peas from the attack of cowpea weevils, Callosobruchus maculates F. (Coleoptera: Bruchidae). - J. Egypt. Ger. Soc. Zool. 19: 29-39.

[52] Taheya, S. M., Al-Moagel, N. H. (1993): Grain insect control agent from tumeric (Curcuma longa L.) rhizome extract. - J. Egypt. Ger. Soc. Zool. 12: 111-130.

[53] Tayoub, G., Odeh, A., Ghanem, I. (2012): Chemical composition and fumigation toxicity of Laurus nobilis L. and Salvia officinalis L. essential oils on larvae of khapra beetle (Trogoderma granarium Everts). - Herba Polonica 58(2): 26-37. 